Article

\title{
How Does Ginsenoside Rh2 Mitigate Adipogenesis in Cultured Cells and Obese Mice?
}

\author{
Longyun Zhang ${ }^{1}$, Carlos Virgous ${ }^{2}$ and Hongwei Si ${ }^{1, *}$ \\ 1 Department of Human Sciences, Tennessee State University, Nashville, TN 37209, USA; \\ geniisofla@gmail.com \\ 2 Animal Care Facility, Meharry Medical College, Nashville, TN 37208, USA; cvirgous@mmc.edu \\ * Correspondence: hsi@tnstate.edu; Tel.: +1-615-963-5443
}

Received: 17 April 2020; Accepted: 19 May 2020; Published: 21 May 2020

\begin{abstract}
Ginsenoside Rh2, an intermediate metabolite of ginseng, but not naturally occurring, has recently drawn attention because of its anticancer effect. However, it is not clear if and how Rh2 inhibits preadipocytes differentiation. In the present study, we hypothesized that ginsenoside Rh2 attenuates adipogenesis through regulating the peroxisome proliferator-activated receptor gamma (PPAR- $\gamma$ ) pathway both in cells and obese mice. Different concentrations of Rh2 were applied both in 3T3-L1 cells and human primary preadipocytes to determine if Rh2 inhibits cell differentiation. Dietary $\mathrm{Rh} 2$ was administered to obese mice to determine if $\mathrm{Rh} 2$ prevents obesity in vivo. The mRNA and protein expression of PPAR- $\gamma$ pathway molecules in cells and tissues were measured by real-time polymerase chain reaction (RT-PCR) and Western blot, respectively. Our results show that Rh2 dose-dependently $(30-60 \mu \mathrm{M})$ inhibited cell differentiation in 3T3-L1 cells $(44.5 \% \pm 7.8 \%$ of control at $60 \mu \mathrm{M})$. This inhibitory effect is accompanied by the attenuation of the protein and/or mRNA expression of adipogenic markers including PPAR- $\gamma$ and CCAAT/enhancer binding protein alpha, fatty acid synthase, fatty acid binding protein 4 , and perilipin significantly $(p<0.05)$. Moreover, Rh2 significantly $(p<0.05)$ inhibited differentiation in human primary preadipocytes at much lower concentrations $(5-15 \mu \mathrm{M})$. Furthermore, dietary intake of Rh2 $(0.1 \mathrm{~g} \mathrm{Rh} 2 / \mathrm{kg}$ diet, w/w for eight weeks) significantly $(p<0.05)$ reduced protein PPAR- $\gamma$ expression in liver and hepatic glutathione reductase and lowered fasting blood glucose. These results suggest that ginsenoside Rh2 dose-dependently inhibits adipogenesis through down-regulating the PPAR- $\gamma$ pathway, and Rh2 may be a potential agent in preventing obesity in vivo.
\end{abstract}

Keywords: ginsenoside Rh2; adipogenesis; PPAR- $\gamma$ pathway; preadipocytes; obese mice

\section{Introduction}

Ginseng (Panax ginseng) has been used as a medicinal herb and functional food in Asia for over 2000 years [1], and it is the fifth most commonly used natural product in the United States [2]. There are four major ginsengs according to the preparation method: fresh ginseng, white ginseng (dehydration of fresh ginseng using sunlight), red ginseng (steaming dry/fresh ginseng at $95-100{ }^{\circ} \mathrm{C}$ for a reasonable time), and black ginseng (nine-time repetitive steaming white ginseng at $95-100{ }^{\circ} \mathrm{C}$ for $3 \mathrm{~h}$ ) [3]. Red ginseng, the most attractive ginseng, accounting 59\% in the South Korean market, is believed to have better health benefits than fresh ginseng and white ginseng, because more saponins and ginsenosides-the bioactive components of ginseng-are produced by the heating process. Particularly, ginsenosides such as Rg3 and Rh2, which are trace or not detectable in fresh or white ginseng, are dramatically increased by this process in red ginseng. This ginsenoside $\mathrm{Rg} 3$ can be transformed to ginsenoside Rh2 by intestinal bacteria or thermal process [4-6]. Both Rg3 and Rh2 
have been reported to have special health benefits, including anticancer [7-9], anti-diabetes [10,11], anti-Alzheimer disease [12], and anti-inflammation [13].

Recently, the anti-obesity effect of ginseng has been extensively investigated [14] because of the worldwide fast increasing obesity prevalence. For instance, Korean red ginseng extracts $(200 \mathrm{mg} / \mathrm{kg}$, i.p. for three weeks) reduced food intakes and decreased the levels of leptin and neuropeptide $Y$ in high-fat diet-fed rats [15]. American ginseng berry juice (oral gavage, once a day, $0.6 \mathrm{~mL} / \mathrm{kg}$ for 10 days) reduced body weight gain in mice [16]. While the anti-obesity effects of ginseng crude extracts/juice have been reported in cells and animals, the only two reports of Rh2 on obesity are controversial. Rh2 promotes fat accumulation at low concentrations $(0.01-1 \mu \mathrm{M})$ by activating glucocorticoid receptor in 3T3-L1 cells [17]; however, at a high level (at 20 and $40 \mu \mathrm{M}$ ), Rh2 attenuates 3T3-L1 cell differentiation [18]. This cell differentiation, named adipogenesis, plays a vital role in adult and childhood obesity development $[19,20]$. In the present study, we hypothesized that ginsenoside $\mathrm{Rh} 2$ inhibits adipogenesis through attenuating the peroxisome proliferator-activated receptor gamma (PPAR- $\gamma$ ) pathway in preadipocytes. The objectives of the present study were to determine if (1) Rh2 dose-dependently attenuates preadipocytes differentiation both in rodent preadipocytes (3T3-L1 cells) and human primary preadipocytes (HPPs); (2) dietary Rh2 intake prevents adipogenesis in obese mice; and (3) Rh2 attenuates adipogenesis by PPAR- $\gamma$ and CCAAT/enhancer binding protein (C/EBP) pathway both in vitro and in vivo.

\section{Results}

\subsection{Ginsenoside Rh2 Dose-Dependently Suppresses 3T3-L1 Differentiation without Cytotoxicity}

Ginsenoside Rh2 $(30,40,50$, or $60 \mu \mathrm{M})$ was added in the medium from day 0 (adding differential inducer 3-isobutyl-1-methylxanthine (IBMX) + dexamethasone + insulin (MDI)) and replaced on day 3 and day 5 in 3T3-L1 cells. On day 7, cells were stained with Oil-Red O to take images or extract fat by adding $100 \%$ isopropanol and measured the absorbance at $490 \mathrm{~nm}$ to evaluate the fat accumulation. As showed in Figure 1A, Rh2 inhibited MDI-induced intracellular fat droplets formation dose-dependently. At $60 \mu \mathrm{M}, \mathrm{Rh} 2$ reduced fat accumulation by up to $46 \%$ of the dimethyl sulfoxide (DMSO) control. We did not show the data on concentrations of $1 \mu \mathrm{M}, 10 \mu \mathrm{M}$, and $20 \mu \mathrm{M}$ because there were no significant effects on differentiation at these concentrations. The toxicity of ginsenoside Rh2 was evaluated by the cell toxicity MTT assay. We found that there was no significant effect on cell viability at the selected level of ginsenoside Rh2 $(10-60 \mu \mathrm{M})$ in 3T3-L1 cells (Figure 1B). However, cells were significantly killed at $80 \mu \mathrm{M}$, which is in line with the previous report that ginsenoside $\mathrm{Rh} 2$ exerted cellular toxicity at doses of 80-160 $\mu \mathrm{M}$ [18]. These results indicate that ginsenoside $\mathrm{Rh} 2 \mathrm{can}$ prevent preadipocytes differentiation in a dose-dependent manner without cytotoxicity.

\subsection{Ginsenoside Rh2 Dose-Dependently Inhibits PPAR- $\gamma$ and C/EBP- $\alpha$ Protein Expressions in 3T3-L1 Cells}

PPAR- $\gamma$ and C/EBP- $\alpha$ are the two transcriptional factors of preadipocyte differentiation, and Rh2 suppressed 3T3-L1cells differentiation as above, we want to know if Rh2 affects protein level of PPAR $-\gamma$ and C/EBP- $\alpha$ during the differentiation process. The Western blot results showed that MDI-induced PPAR- $\gamma$ (Figure 2A) and C/EBP- $\alpha$ (Figure 2B) protein expressions were dose-dependently reduced by Rh2 in 3T3-L1 cells, the same pattern of the inhibitory effect of Rh2 in fat accumulation (Figure 1A). Particularly, protein expressions of PPAR- $\gamma$ (Figure 2A) and C/EBP- $\alpha$ (Figure 2B) were significantly reduced to $4.9 \%(p<0.01)$ and $6.5 \%(p<0.01)$ of DMSO, respectively, by Rh2 at $60 \mu \mathrm{M}$. Therefore, ginsenoside Rh2 attenuates PPAR- $\gamma$ and C/EBP- $\alpha$ protein expression, thereby inhibiting the adipogenesis process. 
A
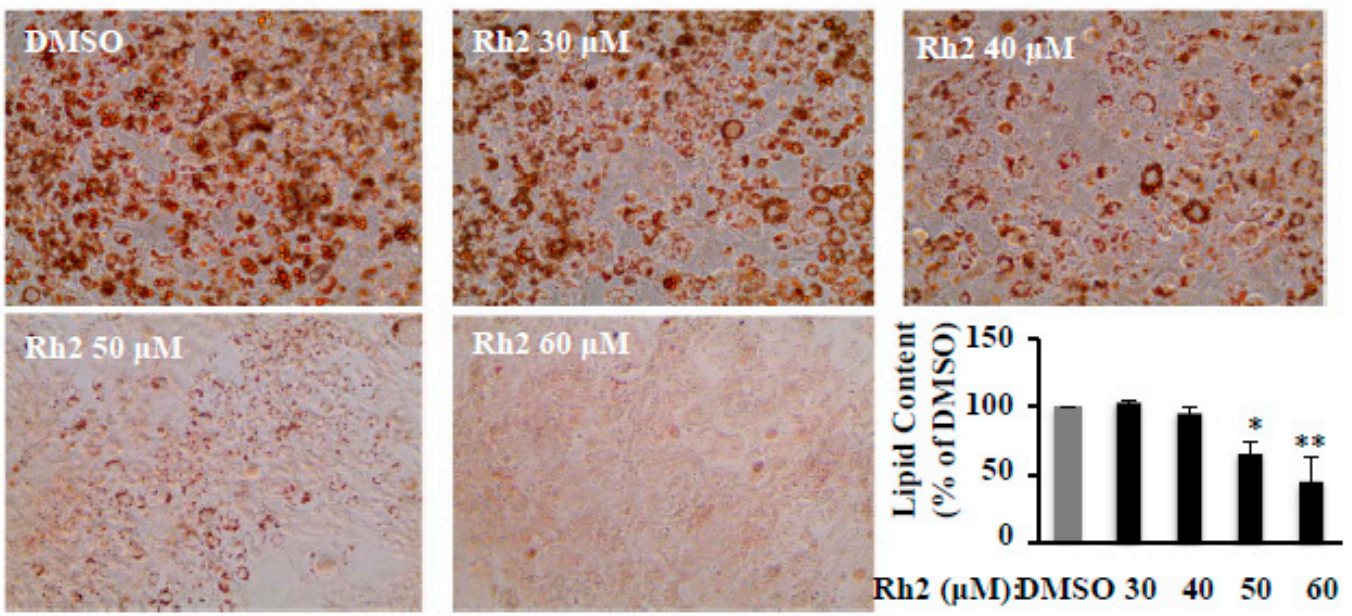

B

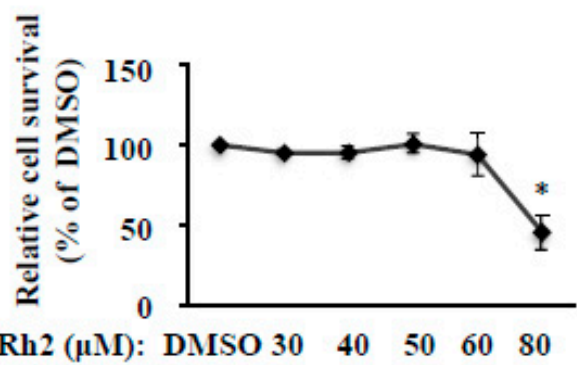

Figure 1. Ginsenoside Rh2 dose-dependently inhibits cell differentiation in 3T3-L1 cells. The cells were induced to differentiation by 3-isobutyl-1-methylxanthine (IBMX) + dexamethasone + insulin (MDI) mixture with/out $\mathrm{Rh} 2$ for seven days, and then stained with Oil-red $\mathrm{O}$ and dissolved in isopropanol. The relative fat accumulation was measured by a Synergy H1 hybrid reader at $490 \mathrm{~nm}$. Oil-Red O representative images of lipid accumulation and the bar graphs are shown (A, $200 \times$ magnification). A cell toxicity study was measured by an MTT assay (B). Values are means \pm SE, $n=4 .{ }^{*} p<0.05$, ** $p<0.01$ vs. dimethyl sulfoxide (DMSO).
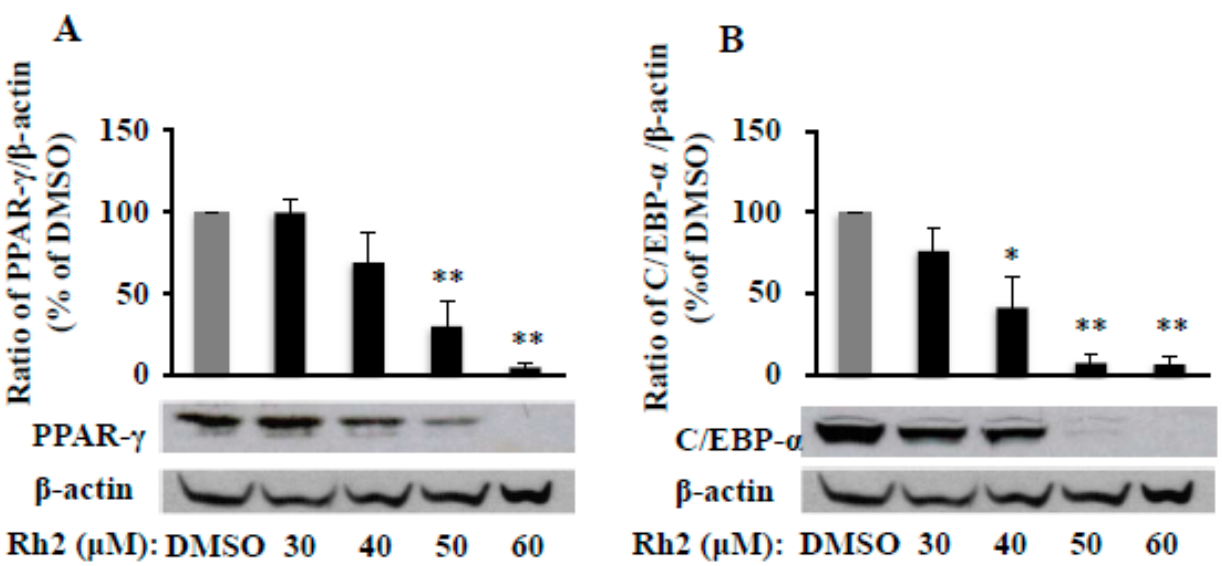

Figure 2. Ginsenoside Rh2 dose-dependently suppresses protein expressions of PPAR- $\gamma$ (A) and CCAAT/enhancer binding protein (C/EBP)- $\alpha(\mathbf{B})$ in 3T3-L1 cells. On day 7, cells treated with various concentrations of $\mathrm{Rh} 2$ were collected to measure peroxisome proliferator-activated receptor gamma (PPAR- $\gamma$ ) and C/EBP- $\alpha$ protein expressions by Western blotting and normalized by $\beta$-actin expression. Values are means $\pm \mathrm{SE}, n=3$. A set of representative images and bar graphs are shown. ${ }^{*} p<0.05,{ }^{* *} p<0.01$ vs. DMSO. 


\subsection{Ginsenoside Rh2 Abolishes MDI-Induced PPAR- $\gamma$ mRNA Expression in 3T3-L1 Cells}

Although Rh2 abolished MDI-induced PPAR- $\gamma$ protein expression, it is worth investigating whether the inhibitory effect of Rh2 on this key molecule is via a transcriptional mechanism. We measured PPAR- $\gamma$ mRNA expression in 3T3-L1 cells using quantitative real-time polymerase chain reaction (PCR). Our results showed that Rh2 dose-dependently inhibited MDI-increased PPAR- $\gamma$ mRNA expression after exposing of 3T3-L1 cells to various concentrations of Rh2 for seven days, notably reduced to $9.6 \%$ of DMSO at $50 \mu \mathrm{M}$ (Figure 3). This effect is very consistent with its impact on fat accumulation (Figure 1A) and PPAR- $\gamma$ protein expression (Figure 2A), suggesting that Rh2 inhibits PPAR- $\gamma$ expression at the transcriptional level and protein synthesis, and thus suppresses adipogenesis in 3T3-L1 cells.

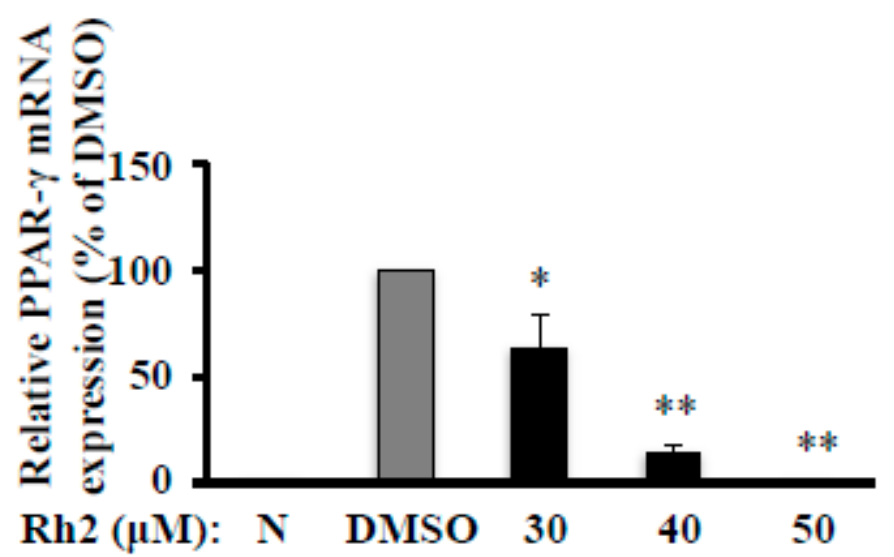

Figure 3. Ginsenoside Rh2 reduces PPAR- $\gamma$ mRNA expression in 3T3-L1 cells. On day 7, cells treated with various concentrations of Rh2 were collected to measure PPAR- $\gamma$ mRNA expression by quantitative real-time polymerase chain reaction (PCR) and normalized by $\beta$-actin expression. Values are means \pm $\mathrm{SE}, n=3 .{ }^{*} p<0.05,{ }^{* *} p<0.01$ vs. DMSO.

\subsection{Ginsenoside Rh2 Attenuates Fat Packing Proteins in 3T3-L1 Cells}

Fat packing is a critical step of adipogenesis, which is implemented by several packing proteins including fatty acid synthase (FAS), fatty acid binding protein 4 (FABP4), and perilipin. We found that ginsenoside Rh2 dose-dependently inhibited protein expression of perilipin (Figure 4A), FAS (Figure 4B), and FABP4 (Figure 4C) on day 7 in 3T3-L1cells. These results matched the patterns of the Rh2 inhibitory effects on fat accumulation, PPAR- $\gamma$, and C/EBP- $\alpha$ protein and mRNA expressions in 3T3-L1 cells, as aforementioned.

\subsection{Ginsenoside Rh2 Dose-Dependently Inhibits Cell Differentiation in Human Primary Preadipocytes}

Although Rh2 dose-dependently inhibited cell differentiation and relevant key molecules' expression in 3T3-L1 cells, the high concentrations $(30-60 \mu \mathrm{M})$ of Rh2 and the characteristics of the 3T3-L1 cell line [21] prevent the application of Rh2 to fight obesity in humans. We recently reported that human primary preadipocytes (HPPs) were more sensitive and required much lower concentrations of the drugs than 3T3-L1 cells in the anti-adipogenic effect [22]. Indeed, compared with the effective concentrations (30-60 $\mu \mathrm{M})$ in 3T3-L1 cells, 5-15 $\mu \mathrm{M}$ Rh2 significantly inhibited fat accumulation in HPPs (Figure 5). This was also demonstrated in the anti-adipogenic effect of ginsenoside Rg3 between HPPs and 3T3-L1 cells in our recent study [23]. These results suggest that $\mathrm{Rh} 2$ has the potential to exert the anti-adipogenic effect in humans. 


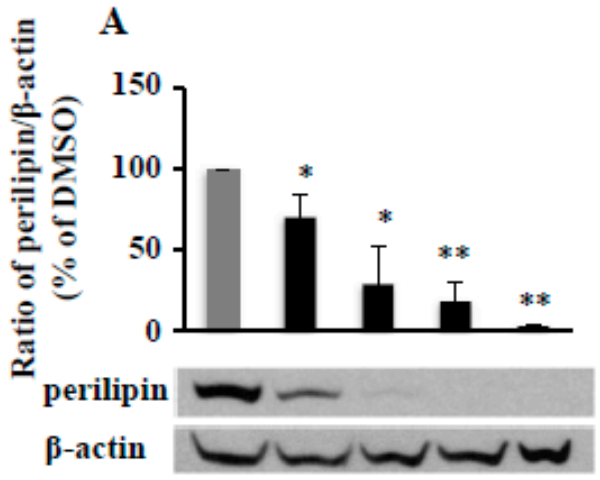

$\operatorname{Rh2}(\mu \mathrm{M})$ : DMSO $30 \quad 40 \quad 50 \quad 60$

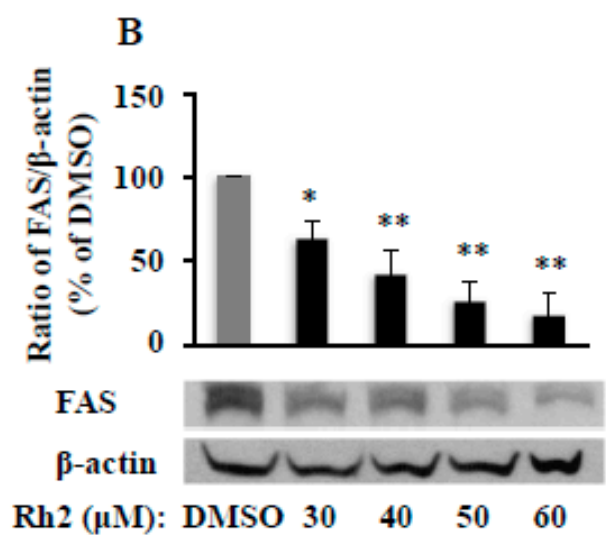

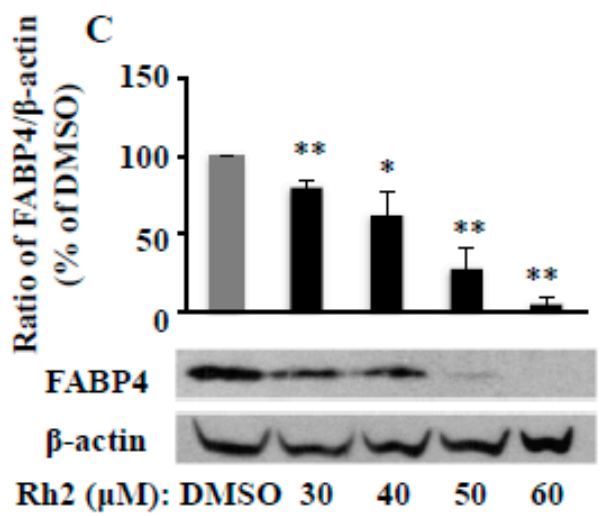

Figure 4. Ginsenoside Rh2 dose-dependently attenuates protein expressions of fat packing proteins perilipin (A), fatty acid synthase (FAS, B), and fatty acid binding protein 4 (FABP4, C) in 3T3-L1 cells. On day 7, cells treated with various concentrations of Rh2 were collected to measure perilipin, FAS, and FABP4 protein expressions by Western blot and normalized by $\beta$-actin expression. Values are means $\pm \mathrm{SE}, n=3$. A set of representative images and bar graphs are shown. ${ }^{*} p<0.05,{ }^{* *} p<0.01$ vs. DMSO.
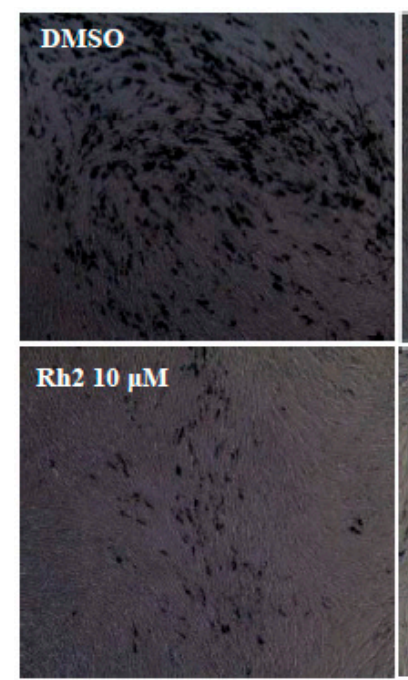

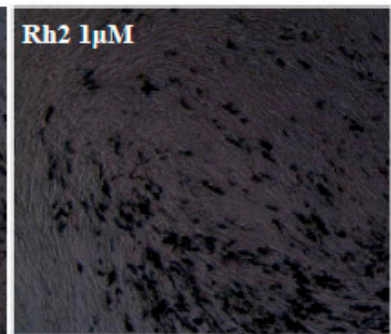

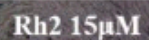
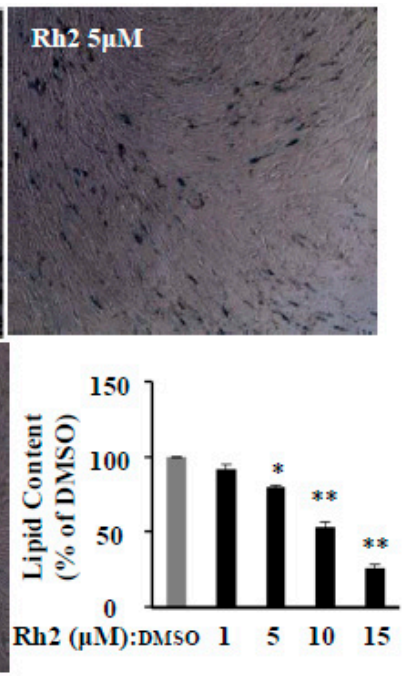

Figure 5. Ginsenoside Rh2 dose-dependently reverses lipid accumulation, protein expressions of differentiation markers in human primary preadipocytes (HPPs). The cells stained with Oil-red O on day 15 were dissolved in isopropanol, and fat accumulation was measured by absorbance using Synergy $\mathrm{H} 1$ hybrid reader at $490 \mathrm{~nm}$. Oil-Red O representative images of lipid accumulation and the average bar graph are shown $(40 \times$ magnification). Values are means $\pm \mathrm{SE}, n=4$. A set of representative images and bar graphs are shown. ${ }^{*} p<0.05,{ }^{* *} p<0.01$ vs. DMSO. 


\subsection{Dietary Ginsenoside Rh2 Reduces Hepatic PPAR- $\gamma$ Expression in Obese Mice}

Because of the complexity of the absorption and metabolism of Rh2, it is essential to test whether dietary supplementation of Rh2 can inhibit PPAR- $\gamma$ expression, and thereby prevent obesity in ob/ob obese mice, a widely used obese animal model. As shown in Figure 6A, dietary intake of Rh2

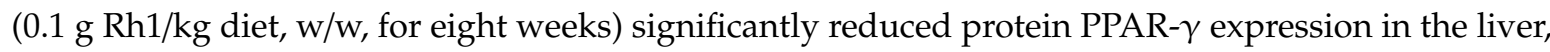
the primary organ of adipogenesis, although we did not found a significant change of PPAR- $\gamma$ expression in white adipose tissues (WATs). The fasting glucose was significantly reduced by Rh2 at the end of the experiment (Table 1), although we did not observe significant changes in the body weight, food intake, weight of the liver, and weight of WATs, as well as glucose tolerance (data not shown) by Rh2. Moreover, levels of hepatic glutathione reductase (GR) and glutathione S-transferase (GST), two major antioxidants molecules, were significantly decreased in the Rh2 group (Table 2). These enzymes are significantly increased in obese animals fed with high-fat diets and contribute to obese-induced complications. Similarly, the obese-increased hepatic GR and GST were reversed by dietary intake of grape seed extract in obese rats [24], which might be because of the oxidative stress-reducing capacity and inhibition of the generation of superoxide anions and hydroxyl-free radicals.

Table 1. Bodyweight gain, food intake, weight of liver, weight of white adipose tissues (WATs), fasting blood glucose, and hepatic antioxidants in obese mice.

\begin{tabular}{cccccccc}
\hline Group & $\begin{array}{c}\text { Body Weight } \\
\text { Gain (g/mouse) }\end{array}$ & $\begin{array}{c}\text { Food Intake } \\
\text { (g/mouse/day) }\end{array}$ & $\begin{array}{c}\text { Liver } \\
\text { Weight (g) }\end{array}$ & $\begin{array}{c}\text { WATs } \\
\text { Weight (g) }\end{array}$ & $\begin{array}{c}\text { Fasting Blood } \\
\text { Glucose } \\
\text { (mg/dL) }\end{array}$ & $\begin{array}{c}\text { Liver Glutathione } \\
\text { Reductase } \\
\text { (nmol/min/mg protein) }\end{array}$ & $\begin{array}{c}\text { Liver Glutathione } \\
\text { S-Transferase } \\
\text { (nmol/min/mg protein) }\end{array}$ \\
\hline SD & $21.6 \pm 1.85$ & $3.85 \pm 0.30$ & $1.78 \pm 0.22$ & $2.71 \pm 0.31$ & $160 \pm 16.9$ & $50.2 \pm 3.77$ & $1171 \pm 53.3$ \\
Rh2 & $24.1 \pm 0.82$ & $3.82 \pm 0.30$ & $1.67 \pm 0.23$ & $2.69 \pm 0.39$ & $132 \pm 11.4 *$ & $38.7 \pm 0.91 *$ & $1044 \pm 17.2^{*}$ \\
\hline
\end{tabular}

Values are means $\pm \mathrm{SE}, n=12 .{ }^{*} p<0.05$ vs. standard diet (SD).

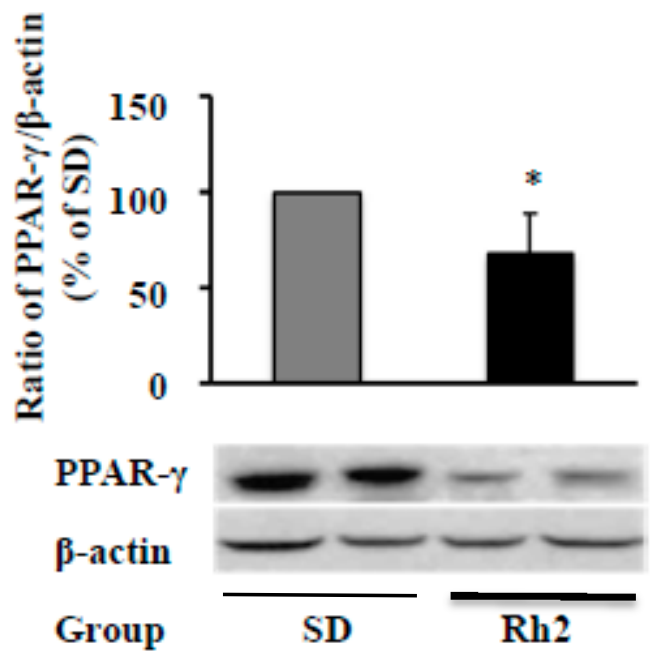

Figure 6. In vivo effects of dietary ginsenoside Rh2 intake. After an eight-week dietary administration of $\mathrm{Rh} 2(0.1 \mathrm{~g} / \mathrm{kg}$ diet $)$, the liver PPAR- $\gamma$ protein expression in mice was determined by Western blot and normalized to $\beta$-actin expression. Values are means $\pm \mathrm{SE}, n=12$. A set of representative images and bar graphs are shown. ${ }^{*} p<0.05$ vs. standard diet (SD).

\section{Discussion}

In the present study, we reported for the first time, to our knowledge, that dietary supplementation Rh2 attenuated hepatic protein expression of PPAR- $\gamma$, a key regulator of adipogenesis and fat metabolism, as well as the improvements in fasting blood glucose and hepatic antioxidants GR and GST in obese mice. We also found that Rh2 dose-dependently inhibited fat accumulation and expressions of PPAR- $\gamma$, C/EBP- $\alpha$, FAS, and perilipin in 3T3-L1 cells. Compared with the required high Rh2 
concentrations (30-60 $\mu \mathrm{M})$ in 3T3-L1 cells, Rh2 significantly inhibited differentiation at much lower levels $(5-15 \mu \mathrm{M})$ in HPPs. The different effective dosages in 3T3-L1 cells and HPPs may be the result of the different characteristics of these two cells that 3T3-L1 cells are from a homogeneous population, but HPPs include both preadipocytes and fibroblast-likes cells, as we discussed [23]. These results confirm our research hypothesis that ginsenoside Rh2 inhibits adipogenesis through attenuating the PPAR- $\gamma$ pathway in both preadipocytes and obese mice.

Ginsenoside Rh2 was not detected in red and black Asian ginseng, while Rg3 was increased by this process $[25,26]$. In American ginseng, Rh2 is not naturally present in both root and leaf; however, heat treatment $\left(100{ }^{\circ} \mathrm{C}, 1.5 \mathrm{~h}\right)$ produced $11.3 \pm 0.5 \mathrm{mg} / \mathrm{g} \mathrm{Rh} 2$ in leaf, but not from heat-treated root [6]. Another study found that a total of $576 \mathrm{mg} / \mathrm{g}$ Rh2 (20(R)-Rh2 + 20(S)-Rh2) can be extracted in American ginseng leaf by the heat extracting process $\left(100{ }^{\circ} \mathrm{C}, 1.5 \mathrm{~h}\right)$ [27]. However, one study found that Rh2 was not detectable in white Asian ginseng, but was detected in white American ginseng (0.007\%), and long-time steaming remarkably increased Rh2 level (0.066\% after $4 \mathrm{~h}$ steaming) in American ginseng [28]. Moreover, Rh2 can be hydrolyzed from Rg3 in the digestive system, and the maximum plasma concentration of Rh2 of $0.48 \mu \mathrm{M}$ can be reached in $2 \mathrm{~h}$ after oral ginsenoside $\operatorname{Rg} 3(50 \mathrm{mg} / \mathrm{kg}) \mathrm{in}$ normal rats [4]. In addition, this degrading process from $\operatorname{Rg} 3$ to $\mathrm{Rh} 2$ can be suppressed by a tumor in rats [4]. In humans and rats, $\mathrm{Rh} 2$ was transformed by intestinal bacteria from $\mathrm{Rg} 3$, which was metabolized in the stomach from $\mathrm{Rb} 1$ and $\mathrm{Rb} 2$, the major naturally presented ginsenosides in fresh ginseng [5,29]. Protopanaxadiol and monooxygenated protopanaxadiol are the metabolites of Rb1, $\mathrm{Rg} 3$, and $\mathrm{Rh} 2$ in rat feces [29]. Therefore, gut microbiota plays a crucial role in Rh2 conversion from $\mathrm{Rb} 1$ and $\mathrm{Rg} 3$. In addition, $\mathrm{Rh} 2$ can be rapidly produced from $\mathrm{Rb} 1$ under the acidic environment (simulated gastric fluid) [30]. Furthermore, the octyl ester derivative of Rh2 (Rh2-O) has a higher cellular uptake (63.24\%) than Rh2 (36.76\%) when incubated with HepG2 cells for $24 \mathrm{~h}$ [10]. Therefore, $\mathrm{Rh} 2$ is an intermediate ginsenoside from $\mathrm{Rg} 3$ or Rb1 by heating, intestinal bacteria, and gastric fluid, and it has a low rate of cellular uptake, but with multiple beneficial effects.

Rh2 promoted fat accumulation at low concentrations $(0.01-1 \mu \mathrm{M})$ by activating glucocorticoid receptor in 3T3-L1 cells [17]; however, at the high level (at 20 and $40 \mu \mathrm{M}$ ), Rh2 attenuated 3T3-L1cell differentiation via activating the adenosine monophosphate (AMP)-activated protein kinase (AMPK) signaling pathway [18]. Our results are in line with this study finding that Rh2 dose-dependently (30-60 $\mu \mathrm{M}$ ) inhibited fat accumulation, and accompanied by the attenuated expressions of critical markers of PPAR- $\gamma, \mathrm{C} / \mathrm{EBP}-\alpha, \mathrm{FAS}, \mathrm{FABP} 4$, and perilipin. The different effect of low level of Rh2 $(1 \mu \mathrm{M})$ between Niu et al. [17] and our study and Hwang et al. [18] is the result of different conditions (no chemical inducer versus cocktail MDI mixture (0.5 mM IBMX, $1 \mu \mathrm{M}$ dexamethasone, and $10 \mu \mathrm{g} / \mathrm{mL}$ insulin)), and the powerful MDI inducer produced strong differentiation overshadows the pro-adipogenesis effect of Rh2 at this low level. We also tested the toxicity of Rh2 using an MTT assay that all concentrations $(30-60 \mu \mathrm{M})$ having anti-adipogenic effects are safe in 3T3-L1 cells.

AMPK is a key regulator of energy dynamics, and it produces ATP and enhances oxidative metabolism and mitochondrial biogenesis, adipogenesis, as well as lipolysis [31-33]. Overexpression of AMPK in mice induces the expression of genes controlling lipid oxidation and mitochondrial $[34,35]$. Activated AMPK may reduce PPAR- $\gamma$ activity and expression in adipocytes [36], and this is supported by the study that Rh2 attenuated 3T3-L1cell differentiation via activating the AMPK signaling pathway [18]. Indeed, red ginseng [37-39] and Rg3, the source of Rh2, all activated AMPK activity [40-42]. Hence, this Rh2-activated AMPK may prevent/reduce obesity by increasing energy expenditure and inhibiting adipogenesis. Moreover, the anti-adipogenic effect of Rh2 may depend on phosphoinositide 3-kinase (PI3K)/Akt pathways and wingless-type MMTV integration site $(\mathrm{WNT}) / \beta$-catenin pathway, which is supported by the fact that the AKT [43] and (WNT)/ $\beta$-catenin pathways [44] are involved in adipogenesis and Rh2 can significantly affect these pathways $[45,46]$.

There is no report that individual dietary Rh2 prevents obesity in animals, although red ginseng crude extract has been reported in preventing obesity in rodent models by reducing leptin level and adipogenesis level [47-49], as well as enhancing fatty acid oxidation and energy expenditures 
via activation of PPAR $\alpha$ in rats (200 mg/kg to 10-week-old, for 32 weeks) [50]. In the present study, we found that dietary intake of Rh2 $(0.01 \%, w / w)$ significantly reduced PPAR- $\gamma$ protein expression in liver, fasting blood glucose, and two major endogenous antioxidant molecules GR and GST in ob/ob mice, although we did not observe significant changes of body weight, food intake, and fat pad. These results indicate that $\mathrm{Rh} 2$ has the potential to fight obesity, at least in the liver, the factory of fat and energy metabolism. Indeed, the prevalence rate of nonalcoholic fatty liver disease (NAFLD) increases with increasing body mass index (BMI). For instance, the prevalence rates of NAFLD are 15\%, $65 \%$, and $85 \%$ in nonobese, obese (BMI $30.0-39.9 \mathrm{~kg} / \mathrm{m}^{2}$ ), and extremely obese patients (BMI $40 \mathrm{~kg} / \mathrm{m}^{2}$ ), respectively [51]. However, because of the limited resources, the only one low dosage $(0.01 \%, \mathrm{w} / \mathrm{w})$ $\mathrm{Rh} 2$ was used in this animal study, which may contribute to the failure of reducing weight gain and fat pads as well as the expression of adipogenic markers including PPAR- $\gamma$, C/EBP- $\alpha$, FAS, and perilipin (which have been confirmed in 3T3-L1 cells). In addition, we did not analyze the adipocyte sizes in WATs because there were no significant changes in body weight and WATs' weight in obese mice. The $\mathrm{Rh} 2$ level in the blood of mice was not measured because of the limited volume of collected blood. If several different higher dosages are used in the next study, and these limitations will be solved, we can make a conclusion on whether the dietary intake of Rh2 prevents obesity in animals.

In summary, we found that $\mathrm{Rh} 2$ dose-dependently inhibited cell differentiation and expressions of adipogenic markers including PPAR- $\gamma$, C/EBP- $\alpha$, FAS, and perilipin in 3T3-L1 cells. HPPs need much lower concentrations of Rh2 in inhibiting differentiation compared with 3T3-L1 cells. This is the first study to find that dietary supplementation Rh2 attenuated hepatic protein expression of PPAR- $\gamma$, a key regulator of adipogenesis and fat metabolism, as well as the improvements in fasting blood glucose and hepatic antioxidants GR and GST in obese mice. These results suggest that ginsenoside Rh2 dose-dependently inhibits preadipocytes differentiation through down-regulating the PPAR- $\gamma$ pathway, and Rh2 may be a potential agent in preventing obesity, although more studies are needed.

\section{Materials and Methods}

\subsection{Chemicals}

The HPPs specific medium fibroblast basal medium plus fibroblast growth kit, serum-free (KS-201-040), was also obtained from ATCC (Manassas, VA, USA). Dulbecco's modified Eagle's medium and penicillin-streptomycin were from Gibco (Grand Island, NY, USA). Fetal bovine serum was purchased from Mediatech (Manassas, VA, USA). Ginsenoside Rh2 (99.9\% purity) was purchased from ChromaDex (Irvine, CA, USA) and was dissolved in DMSO, aliquots at $100 \mathrm{mM}$, and stored in $\mathrm{a}-20{ }^{\circ} \mathrm{C}$ freezer. Insulin from Roche (Mannheim, Germany) and 3-isobutyl-1-methylxanthine (IBMX), dexamethasone, and rosiglitazone from Sigma-Aldrich (St Louis, MO, USA) were used to induce adipocyte differentiation. Specific antibodies for $\beta$-actin, C/EBP- $\alpha$, FABP4, FAS, PPAR- $\gamma$, and perilipin were purchased from Cell Signaling Technology (Danvers, MA, USA). RNeasy Mini Kit was purchased from Qiagen (Valencia, CA, USA) and iTaq Universal SYBR Green One-Step Kit was purchased from Bio-Rad (Hercules, CA, USA). SuperSignal West Dura chemiluminescence kit was from ThermoFisher Scientific (Fair Lawn, NJ, USA). TACS MTT cell proliferation assay kit was purchased from Trevigen (Gaithersburg, MD, USA). Dimethyl sulfoxide (DMSO) was purchased from Sigma (St Louis, MO, USA), while $10 \%$ buffered formalin phosphate and 2-propanol were purchased from Fisher Scientific (Fair Lawn, NJ, USA). Oil-red O solution was purchased from Electron Microscopy Science (Hatfield, PA, USA).

\subsection{Cell Differentiation}

3T3-L1 preadipocytes (from ATCC, Manassas, VA, USA) were cultured in 12-well plates with Dulbecco's modified Eagle medium (DMEM) high glucose containing 1\% penicillin-streptomycin (PS) and $10 \%$ fetal bovine serum (FBS). To induce differentiation, two-day post-confluent preadipocytes were changed with cultural medium (DMEM with $1 \%$ PS and 10\% FBS) supplemented with cocktail 
mixture (MDI: $0.5 \mathrm{mM}$ IBMX, $1 \mu \mathrm{M}$ dexamethasone, and $10 \mu \mathrm{g} / \mathrm{mL}$ insulin) on day 0 . After three days, the cells were then maintained in normal cultural medium with $10 \mu \mathrm{g} / \mathrm{mL}$ insulin. The 3T3-L1 cells need seven days to accomplish the differentiation process. Meanwhile, the cells were treated with various concentrations of Rh2 during the whole differentiation process from day 0 to day 7, as previously described [52]. Passages between 5 and 25 of 3T3-L1 cells were used in all experiments.

Human primary preadipocytes (HPPs, from ATCC, Manassas, VA, USA) were maintained at $37^{\circ} \mathrm{C}$ and $5 \% \mathrm{CO}_{2}$ in fibroblast basal medium plus fibroblast growth kit-serum-free (ATCC, KS-201-040) with biotin $(33 \mu \mathrm{M})$ and pantothenate panthothenate $(17 \mu \mathrm{M})$. After full confluent, cell differentiation (day 0 ) was induced with a hormone cocktail containing $0.5 \mathrm{mM}$ IBMX, $1 \mu \mathrm{M}$ dexamethasone, $1 \mu \mathrm{M}$ rosiglitazone, and $10 \mu \mathrm{g} / \mathrm{mL}$ insulin in the growth medium. After three days, the medium was changed to normal growth medium containing $10 \mu \mathrm{g} / \mathrm{mL}$ insulin every three days until day 15 . The cells were treated with various concentrations of Rh2 during the whole differentiation process from day 0 to day 15, as we described [22]. Passages between 3 and 6 of HPPs were used in all experiments.

\subsection{Oil-Red O Staining}

To determine the adipogenesis and fat accumulation in the adipocytes, 3T3-L1 cells (day 7) and HPPs (day 15) were stained with Oil-red O. The cells were gently washed with phosphate-buffer saline (PBS) once and fixed with $10 \%$ formalin for $1 \mathrm{~h}$ at $4{ }^{\circ} \mathrm{C}$. The fixed cells were washed with PBS three times. The cells were then stained with filtered Oil-red O solution for $30 \mathrm{~min}$ at room temperature and then washed five times with water to remove the unstained Oil-red O solution. Fat droplets in the adipocytes were stained as red; images were taken under an optical microscope. The relative fat accumulation has dissolved the dye in 100\% isopropanol and measured using a Synergy H1 hybrid reader (BioTek Instruments, Inc. Winooski, VT) at $490 \mathrm{~nm}$, as we described [22].

\subsection{Cell Viability Assay}

To test whether Rh2 directly kills cells at the selected concentrations, TACS MTT cell proliferation assay (Trevigen, Gaithersburg, MD, USA) was conducted to evaluate cell viability according to the manufactory's instruction, as we described [23]. Briefly, 3T3-L1 cells were seeded in 12-well plates (about $20 \%$ confluent) with different dosages of Rh2 from $30 \mu \mathrm{M}$ to $300 \mu \mathrm{M}$ for $72 \mathrm{~h}$. Cells were then incubated with MTT reagent $(100 \mu \mathrm{L}$ per well) for $4 \mathrm{~h}$ and added detergent reagent $(500 \mu \mathrm{L}$ each well) and incubated in the dark for $4 \mathrm{~h}$. The relative cell viability was determined by the absorbance at $570 \mathrm{~nm}$ using a Synergy H1 hybrid reader (BioTek Instruments, Inc. Winooski, VT).

\subsection{Animals}

Four-week-old male obese leptin-deficient mice (C57BL/6J-Lep ${ }^{\text {ob }}$, ob/ob, Jackson Laboratory, Bar Harbor, ME, USA) were randomly divided into two groups (12 mice/group), which were fed with either AIN-93G mineral mix standard food (powder) [53], or standard food containing $0.01 \%$ ginsenoside Rh2 (0.1 g Rh2/kg diet, w/w, mixed Rh2 with standard powder food, and fed in food jar) for eight weeks. This dosage was calculated based on previous whole ginseng extracts in animals [47-50], and our in vitro studies $(0.5 \%$ whole ginseng extracts $\times 20 \%$ of $R b 1$ on the whole extracts $=0.01 \%)$. The detailed compositions of diets are listed in Table 2. All animals were maintained at constant temperature and humidity with a 12:12 h light/dark cycle permitted consumption of water and food ad libitum. Bodyweight and food intake were measured weekly throughout the study. At the end of the study, all mice were fasted overnight and euthanized with $\mathrm{CO}_{2}$, according to the American Veterinary Medical Association guidelines. Blood, liver, and fat tissues were collected and prepared for blood glucose, antioxidant activity, and relevant biomarkers analyses. All experimental procedures were approved by the Institutional Animal Care and Use Committee at Tennessee State University following the National Institutes of Health Guidelines for the Care and Use of Laboratory Animals. 
Table 2. Compositions of standard AIN-93G diet and Rh2 supplemented diet.

\begin{tabular}{|c|c|c|}
\hline Ingredient & Standard Diet (g/kg diet) & Rh2 Supplemented Diet (g/kg diet) \\
\hline Cornstarch & 466 & 466 \\
\hline Casein $(>85 \%$ protein $)$ & 140 & 140 \\
\hline Dextrinized cornstarch (>90\% tetrasaccharides) & 155 & 155 \\
\hline Sucrose & 100 & 100 \\
\hline Soybean oil & 40.0 & 40.0 \\
\hline Fiber & 50.0 & 50.0 \\
\hline Mineral mix (AIN-93M-MX) & 35.0 & 35.0 \\
\hline Vitamin mix (AIN-93-vx) & 10.0 & 10.0 \\
\hline L-Cystine & 1.80 & 1.80 \\
\hline Choline bitartrate & 2.50 & 2.50 \\
\hline Ter-butyhydroquinone & 0.008 & 0.008 \\
\hline Ginsenoside Rh2 & 0.00 & 0.10 \\
\hline Total & 1000 & 1000 \\
\hline
\end{tabular}

\subsection{Protein Extraction}

At the end of the differentiation process with/out treatments, 3T3-L1 cells and HPPs were collected to extract proteins, as we described [23]. Briefly, cells were rinsed once with PBS and added with mammalian protein extraction buffer. Cells were then scraped off and collected in $1.5 \mathrm{~mL}$ tube and sonicated on ice for $15 \mathrm{~s}$ three times, with a $15 \mathrm{~s}$ interval. After centrifuging $10 \mathrm{~min}$ at $12,000 \times \mathrm{g}$, the supernatant was collected as a protein sample. Sample protein concentration was measured using a Pierce BCA protein assay kit. An equal amount of protein of samples was mixed with $2 \times$ Western blot sample buffer and heated at $95{ }^{\circ} \mathrm{C}$ for $5 \mathrm{~min}$, and then subjected to Western blot analysis.

Animal tissues liver or white adipose tissues (WATs) collected from the in vivo study were weighted (about $50 \mathrm{mg}$ each mouse) and added in mammalian protein extraction buffer with proteinase inhibitor cocktail (Sigma-Aldrich). After cutting 30 times, samples were homogenized by the Precellys 24 tissue homogenizer on ice three times, $15 \mathrm{~s}$ each time. Then, samples were centrifuged $10 \mathrm{~min}$ at $12,000 \times g$, and supernatants were collected as protein sample. For fat tissue, about $20 \mathrm{mg}$ fat was put into the specific adipose tissue protein extraction buffer (HEPES, $50 \mathrm{mM} ; \mathrm{NaCl}, 150 \mathrm{mM}$; glycerol, 10\%; Triton X-100, 1\%) with proteinase inhibitor cocktail (Sigma-Aldrich). After 30 times cutting, samples were homogenized by Precellys 24 tissue homogenizer on ice three times, $15 \mathrm{~s}$ each time. Then, samples were centrifuged $20 \mathrm{~min}$ at $18,000 \times \mathrm{g}$ at $4{ }^{\circ} \mathrm{C}$. After removing the fat cake from the top, the supernatant was transferred to a new tube as a protein sample. Sample protein concentration was measured using a Pierce BCA protein assay kit. The samples were directly used to measure antioxidant levels as below. For Western blot, the normalized protein samples were mixed with $2 \times$ Western blot sample buffer and heated at $95^{\circ} \mathrm{C}$ for $5 \mathrm{~min}$, and then subjected to Western blot analysis.

\subsection{Western Blot}

Protein samples from cultured cells and animal tissues were analyzed by Western blot, as we described [23]. Briefly, samples were separated by 10\% SDS-PAGE, and the membrane was blocked for $1 \mathrm{~h}$ with Tris-buffered saline-Tween (TBST) containing 5\% skim milk at room temperature. After washing 3 times with TBST, the membrane was incubated with the relevant primary antibody at $4{ }^{\circ} \mathrm{C}$ overnight. On the next day, the membrane was washed three times with TBST and then incubated with secondary antibody for one hour at room temperature. Specific bands were detected by SuperSignal West Dura chemiluminescence (ThermoFisher Scientific), and visualization was performed by exposure of the membranes to X-ray films. Band intensities were quantified by ImageJ software. The value of the specific protein was normalized by the expression of $\beta$-actin and expressed as the percentage of the control. 


\subsection{Total RNA Isolation and Quantitative Real-Time PCR Analysis}

At the end of the adipogenic process, total RNA from 3T3-L1 adipocytes was isolated using the RNeasy Mini Kit (Qiagen, Valencia, CA, USA), as we described [23]. According to the manufacturer's instructions, $30 \mathrm{ng}$ sample of total RNA was applied in the real-time quantitative PCR (SYBR green) analysis using a Bio-Rad iTaq Universal SYBR Green One-step Kit. Designed primers were as follows: PPAR- $\gamma$ forward: TCG CTG ATG CAC TGC CTA TG, PPAR- $\gamma$ reverse: GAG AGG TCC ACA GAG CTG ATT [54]; $\beta$-actin forward: AGC CTT CCT TCT TGG GTA TGG, $\beta$-actin reverse: CAC TTG CGG TGC ACG ATG GAG [55]. The optimized reaction cycles: cDNA synthesis $10 \mathrm{~min}$ at $50^{\circ} \mathrm{C}$, reverse transcriptase inactivation $5 \mathrm{~min}$ at $95^{\circ} \mathrm{C}, 45$ cycles for PCR and detection, $10 \mathrm{~s}$ at $95{ }^{\circ} \mathrm{C}$, and $30 \mathrm{~s}$ at $60{ }^{\circ} \mathrm{C}$. Relative gene expression was normalized by the $\beta$-actin expression and calculated using the $2^{-\Delta \Delta \mathrm{Ct}}$ method.

\subsection{Hepatic Antioxidants}

Extracted liver protein samples from above were used to evaluate levels of antioxidants glutathione reductase (GR) and glutathione S-transferase (GST) using a colorimetric detection assay kit according to the manufacturer's instructions (Cayman Chemicals). Briefly, the samples were treated with metaphosphoric acid and triethanolamine to remove protein to avoid interferences owing to particulates and sulfhydryl groups on proteins in the assay. Then, $50 \mu \mathrm{L}$ of the sample was added with assay cocktail and incubated for $25 \mathrm{~min}$; concentrations of GR and GST were measured at $405 \mathrm{~nm}$ and calculated from the standard curve, as previously described [56]. Samples were tested in duplicate using Synergy H1 hybrid reader (BioTek Instruments, Inc. Winooski, VT). The value was normalized by the protein level and expressed as $\mathrm{nmol} / \mathrm{min} / \mathrm{mg}$ protein.

\subsection{Statistical Analyses}

All values of in vitro studies were presented as means \pm SEM of at least three independent experiments performed in triplicate. For the animal study, 12 mice/group was determined by conducting a power analysis (using GPOWER software) for a one-way analysis of variance (ANOVA) at a type error level of 5\%. The values of in vivo studies were presented as means \pm SEM of 12 mice. All data were analyzed with one-way ANOVA and significant differences between treatment groups were further analyzed using Tukey test. Differences with a $p$-value $<0.05$ were considered significant.

Author Contributions: H.S. designed the research project; L.Z. and H.S. performed the experiments, analyzed data, wrote the manuscript. C.V. and H.S. revised the manuscript. All authors have read and agreed to the published version of the manuscript

Funding: This work was supported by a grant from the National Institute of Food and Agriculture in the United States Department of Agriculture (TENX-2011-0255 to Hongwei Si).

Conflicts of Interest: The authors declare no conflict of interest.

\section{Abbreviations}

$\begin{array}{ll}\text { BMI } & \text { body mass index } \\ \text { C/EBP- } \alpha & \text { CCAAT/enhancer binding protein-alpha } \\ \text { DMEM } & \text { Dulbecco's modified Eagle's medium } \\ \text { DMSO } & \text { dimethyl sulfoxide } \\ \text { FAS } & \text { fatty acid synthase } \\ \text { FABP4 } & \text { fatty acid binding protein } 4 \\ \text { GR } & \text { glutathione reductase } \\ \text { GST } & \text { glutathione S-transferase } \\ \text { HPPs } & \text { human primary preadipocytes } \\ \text { IBMX } & \text { 3-isobutyl-1-methylxanthine }\end{array}$




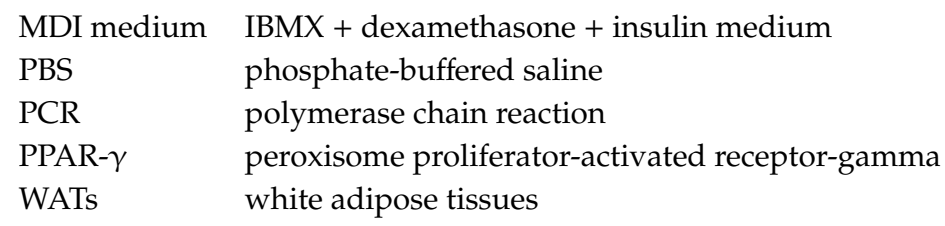

\section{References}

1. Baeg, I.H.; So, S.H. The world ginseng market and the ginseng (Korea). J. Ginseng Res. 2013, 37, 1-7. [CrossRef] [PubMed]

2. Barnes, P.M.; Bloom, B.; Nahin, R.L. Complementary and Alternative Medicine Use Among Adults and Children: United States. 2007. Available online: https://www.cdc.gov/nchs/data/nhsr/nhsr012.pdf (accessed on 21 May 2020).

3. Gui, Y.; Ryu, G.H. Effects of extrusion cooking on physicochemical properties of white and red ginseng (powder). J. Ginseng Res. 2014, 38, 146-153. [CrossRef] [PubMed]

4. Fan, H.; Xiao-Ling, S.; Yaliu, S.; Ming-Ming, L.; Xue, F.; Xian-Sheng, M.; Li, F. Comparative Pharmacokinetics of Ginsenoside Rg3 and Ginsenoside Rh2 after Oral Administration of Ginsenoside Rg3 in Normal and Walker 256 Tumor-bearing Rats. Pharmacogn. Mag. 2016, 12, 21-24.

5. Bae, E.A.; Han, M.J.; Choo, M.K.; Park, S.Y.; Kim, D.H. Metabolism of 20(S)- and 20(R)-ginsenoside Rg3 by human intestinal bacteria and its relation to in vitro biological activities. Biol. Pharm. Bull. 2002, 25, 58-63. [CrossRef]

6. Popovich, D.G.; Kitts, D.D. Generation of ginsenosides Rg3 and Rh2 from North American ginseng. Phytochemistry 2004, 65, 337-344. [CrossRef]

7. Wang, C.Z.; Aung, H.H.; Zhang, B.; Sun, S.; Li, X.L.; He, H.; Xie, J.T.; He, T.C.; Du, W.; Yuan, C.S. Chemopreventive effects of heat-processed Panax quinquefolius root on human breast cancer cells. Anticancer. Res. 2008, 28, 2545-2551.

8. Zhang, H.; Gong, J.; Zhang, H.; Kong, D. Induction of apoptosis and reversal of permeability glycoprotein-mediated multidrug resistance of MCF-7/ADM by ginsenoside Rh2. Int. J. Clin. Exp. Pathol. 2015, 8, 4444-4456.

9. Zhang, Q.; Hong, B.; Wu, S.; Niu, T. Inhibition of prostatic cancer growth by ginsenoside Rh2. Tumour Biol. 2015, 36, 2377-2381. [CrossRef]

10. Chen, F.; Deng, Z.Y.; Zhang, B.; Xiong, Z.X.; Zheng, S.L.; Tan, C.L.; Hu, J.N. Esterification of Ginsenoside Rh2 Enhanced Its Cellular Uptake and Antitumor Activity in Human HepG2 Cells. J. Agric. Food Chem. 2016, 64, 253-261. [CrossRef]

11. Wang, Y.; Wang, H.; Liu, Y.; Li, C.; Qi, P.; Bao, J. Antihyperglycemic effect of ginsenoside Rh2 by inducing islet beta-cell regeneration in mice. Horm. Metab. Res. 2012, 44, 33-40.

12. Chen, F.; Eckman, E.A.; Eckman, C.B. Reductions in levels of the Alzheimer's amyloid beta peptide after oral administration of ginsenosides. FASEB J. 2006, 20, 1269-1271. [CrossRef]

13. Cho, Y.S.; Kim, C.H.; Kim, H.N.; Ha, T.S.; Ahn, H.Y. Ginsenoside Rg3 inhibits lipopolysaccharide-induced adhesion molecule expression in human umbilical vein endothelial cell and C57BL/6 mice. Pharmazie 2014, 69, 818-822.

14. Siraj, F.M.; Kim, Y.J.; Natarajan, S.; Jung, S.K.; Yang, D.U.; Yang, D.C. Ginseng and obesity: Observations from assorted perspectives. Food Sci. Biotechnol. 2014, 23, 1007-1016. [CrossRef]

15. Kim, J.H.; Hahm, D.H.; Yang, D.C.; Kim, J.H.; Lee, H.J.; Shim, I. Effect of crude saponin of Korean red ginseng on high-fat diet-induced obesity in the rat. J. Pharmacol. Sci. 2005, 97, 124-131. [CrossRef]

16. Xie, J.T.; Wang, C.Z.; Ni, M.; Wu, J.A.; Mehendale, S.R.; Aung, H.H.; Foo, A.; Yuan, C.S. American ginseng berry juice intake reduces blood glucose and body weight in ob/ob mice. J. Food Sci. 2007, 72, S590-S594. [CrossRef]

17. Niu, C.S.; Yeh, C.H.; Yeh, M.F.; Cheng, J.T. Increase of adipogenesis by ginsenoside (Rh2) in 3T3-L1 cell via an activation of glucocorticoid receptor. Horm. Metab. Res. 2009, 41, 271-276. [CrossRef]

18. Hwang, J.-T.; Kim, S.-H.; Lee, M.-S.; Kim, S.H.; Yang, H.-J.; Kim, M.-J.; Kim, H.-S.; Ha, J.; Kim, M.S.; Kwon, D.Y. Anti-obesity effects of ginsenoside Rh2 are associated with the activation of AMPK signaling pathway in 3T3-L1 adipocyte. Biochem. Biophys. Res. Commun. 2007, 364, 1002-1008. [CrossRef] 
19. van Harmelen, V.; Skurk, T.; Rohrig, K.; Lee, Y.M.; Halbleib, M.; Aprath-Husmann, I.; Hauner, H. Effect of BMI and age on adipose tissue cellularity and differentiation capacity in women. Int. J. Obes. Relat. Metab. Disord. 2003, 27, 889-895. [CrossRef]

20. Spalding, K.L.; Arner, E.; Westermark, P.O.; Bernard, S.; Buchholz, B.A.; Bergmann, O.; Blomqvist, L.; Hoffstedt, J.; Naslund, E.; Britton, T.; et al. Dynamics of fat cell turnover in humans. Nature 2008, 453, 783-787. [CrossRef]

21. Ruiz-Ojeda, F.J.; Rupérez, A.I.; Gomez-Llorente, C.; Gil, A.; Aguilera, C.M. Cell models and their application for studying adipogenic differentiation in relation to obesity: A review. Int. J. Mol. Sci. 2016, 17, 1040. [CrossRef]

22. Ahmed, B.; Liu, S.; Si, H. Antiadipogenic effects and mechanisms of combinations of genistein, epigallocatechin-3-gallate, and/or resveratrol in preadipocytes. J. Med. Food 2017, 20, 162-170. [CrossRef]

23. Zhang, L.; Zhang, L.; Wang, X.; Si, H. Anti-adipogenic effects and mechanisms of ginsenoside Rg3 in pre-adipocytes and obese mice. Front. Pharmacol. 2017, 8, 113. [CrossRef]

24. Fernandez-Iglesias, A.; Pajuelo, D.; Quesada, H.; Diaz, S.; Blade, C.; Arola, L.; Salvado, M.J.; Mulero, M. Grape seed proanthocyanidin extract improves the hepatic glutathione metabolism in obese Zucker rats. Mol. Nutr. Food Res. 2014, 58, 727-737. [CrossRef]

25. Kim, S.J.; Shin, J.Y.; Ko, S.K. Changes in the contents of prosapogenin in Red ginseng (Panax ginseng) depending on the extracting conditions. J. Ginseng Res. 2016, 40, 86-89. [CrossRef]

26. Lee, S.A.; Jo, H.K.; Im, B.O.; Kim, S.; Whang, W.K.; Ko, S.K. Changes in the Contents of Prosapogenin in the Red Ginseng (Panax ginseng) Depending on Steaming Batches. J. Ginseng Res. 2012, 36, 102-106. [CrossRef]

27. Popovich, D.G.; Kitts, D.D. Mechanistic studies on protopanaxadiol, Rh2, and ginseng (Panax quinquefolius) extract induced cytotoxicity in intestinal Caco-2 cells. J. Biochem. Mol. Toxic. 2004, 18, 143-149. [CrossRef]

28. Wang, C.Z.; Aung, H.H.; Ni, M.; Wu, J.A.; Tong, R.B.; Wicks, S.; He, T.C.; Yuan, C.S. Red American ginseng: Ginsenoside constituents and antiproliferative activities of heat-processed Panax quinquefolius roots. Planta Medica 2007, 73, 669-674. [CrossRef]

29. Qian, T.; Cai, Z. Biotransformation of ginsenosides Rb1, $\mathrm{Rg} 3$ and $\mathrm{Rh} 2$ in rat gastrointestinal tracts. Chin. Med. 2010, 5, 19. [CrossRef]

30. Shen, H.; Leung, W.I.; Ruan, J.Q.; Li, S.L.; Lei, J.P.; Wang, Y.T.; Yan, R. Biotransformation of ginsenoside Rb1 via the gypenoside pathway by human gut bacteria. Chin. Med. 2013, 8, 22. [CrossRef]

31. Hardie, D.G.; Scott, J.W.; Pan, D.A.; Hudson, E.R. Management of cellular energy by the AMP-activated protein kinase system. FEBS Lett. 2003, 546, 113-120. [CrossRef]

32. Hardie, D.G. Minireview: The AMP-activated protein kinase cascade: The key sensor of cellular energy status. Endocrinology 2003, 144, 5179-5183. [CrossRef] [PubMed]

33. Hardie, D.G. AMP-activated/SNF1 protein kinases: Conserved guardians of cellular energy. Nat. Rev. Mol. Cell Biol. 2007, 8, 774-785. [CrossRef] [PubMed]

34. Long, Y.; Barnes, B.; Mahlapuu, M.; Steiler, T.; Martinsson, S.; Leng, Y.; Wallberg-Henriksson, H.; Andersson, L.; Zierath, J. Role of AMP-activated protein kinase in the coordinated expression of genes controlling glucose and lipid metabolism in mouse white skeletal muscle. Diabetologia 2005, 48, 2354-2364. [CrossRef] [PubMed]

35. Garcia-Roves, P.M.; Osler, M.E.; Holmström, M.H.; Zierath, J.R. Gain-of-function R225Q mutation in AMP-activated protein kinase $\gamma 3$ subunit increases mitochondrial biogenesis in glycolytic skeletal muscle. J. Biol. Chem. 2008, 283, 35724-35734. [CrossRef]

36. Kajita, K.; Mune, T.; Ikeda, T.; Matsumoto, M.; Uno, Y.; Sugiyama, C.; Matsubara, K.; Morita, H.; Takemura, M.; Seishima, M.; et al. Effect of fasting on PPARgamma and AMPK activity in adipocytes. Diabetes. Res. Clin. Pract. 2008, 81, 144-149. [CrossRef]

37. Lee, H.J.; Lee, Y.-H.; Park, S.K.; Kang, E.S.; Kim, H.-J.; Lee, Y.C.; Choi, C.S.; Park, S.E.; Ahn, C.W.; Cha, B.S. Korean red ginseng (Panax ginseng) improves insulin sensitivity and attenuates the development of diabetes in Otsuka Long-Evans Tokushima fatty rats. Metab. Clin. Exp. 2009, 58, 1170-1177. [CrossRef]

38. Jeong, K.J.; Kim, G.W.; Chung, S.H. AMP-activated protein kinase: An emerging target for ginseng. J. Ginseng Res. 2014, 38, 83-88. [CrossRef]

39. Yuan, H.-D.; Shin, E.-J.; Chung, S.-H. Anti-diabetic effect and mechanism of Korean red ginseng in C57BL/KsJ db/db mice. J. Ginseng Res. 2008, 32, 187-193. 
40. Hwang, J.T.; Lee, M.S.; Kim, H.J.; Sung, M.J.; Kim, H.Y.; Kim, M.S.; Kwon, D.Y. Antiobesity effect of ginsenoside Rg3 involves the AMPK and PPAR- $\gamma$ signal pathways. Phytother. Res. 2009, 23, 262-266. [CrossRef]

41. Park, M.W.; Ha, J.; Chung, S.H. 20 (S)-ginsenoside Rg3 enhances glucose-stimulated insulin secretion and activates AMPK. Biol. Pharm. Bull. 2008, 31, 748-751. [CrossRef]

42. Lee, S.; Lee, M.-S.; Kim, C.-T.; Kim, I.-H.; Kim, Y. Ginsenoside Rg3 reduces lipid accumulation with AMP-activated protein kinase (AMPK) activation in HepG2 cells. Int. J. Mol. Sci. 2012, 13, 5729-5739. [CrossRef] [PubMed]

43. Kim, H.; Sakamoto, K. (-)-Epigallocatechin gallate suppresses adipocyte differentiation through the MEK/ERK and PI3K/Akt pathways. Cell Biol. Int. 2011, 36, 147-153. [CrossRef]

44. Lee, H.; Bae, S.; Yoon, Y. The anti-adipogenic effects of (-)epigallocatechin gallate are dependent on the WNT/beta-catenin pathway. J. Nutr. Biochem. 2013, 24, 1232-1240. [CrossRef]

45. Chen, Y.; Liu, Z.H.; Xia, J.; Li, X.P.; Li, K.Q.; Xiong, W.; Li, J.; Chen, D.L. 20(S)-ginsenoside Rh2 inhibits the proliferation and induces the apoptosis of KG-1a cells through the Wnt/beta-catenin signaling pathway. Oncol. Rep. 2016, 36, 137-146. [CrossRef]

46. Guan, N.; Huo, X.; Zhang, Z.; Zhang, S.; Luo, J.; Guo, W. Ginsenoside Rh2 inhibits metastasis of glioblastoma multiforme through Akt-regulated MMP13. Tumour Biol. 2015, 36, 6789-6795. [CrossRef]

47. Lee, Y.-S.; Cha, B.-Y.; Yamaguchi, K.; Choi, S.-S.; Yonezawa, T.; Teruya, T.; Nagai, K.; Woo, J.-T. Effects of Korean white ginseng extracts on obesity in high-fat diet-induced obese mice. Cytotechnology 2010, 62, 367-376. [CrossRef]

48. Song, Y.B.; An, Y.R.; Kim, S.J.; Park, H.W.; Jung, J.W.; Kyung, J.S.; Hwang, S.Y.; Kim, Y.S. Lipid metabolic effect of Korean red ginseng extract in mice fed on a high-fat diet. J. Sci. Food Agric. 2012, 92, 388-396. [CrossRef]

49. Lee, S.H.; Lee, H.J.; Lee, Y.H.; Lee, B.W.; Cha, B.S.; Kang, E.S.; Ahn, C.W.; Park, J.S.; Kim, H.J.; Lee, E.Y. Korean red ginseng (Panax ginseng) improves insulin sensitivity in high fat fed Sprague-Dawley rats. Phytother. Res. 2012, 26, 142-147. [CrossRef]

50. Lee, H.J.; Park, S.K.; Han, S.J.; Kim, S.H.; Hur, K.Y.; Kang, E.S.; Ahn, C.W.; Cha, B.S.; Kim, K.S.; Lee, H.C. Korean Red Ginseng Activates AMPK in Skeletal Muscle and Liver. Diabetes 2007, 56, A448.

51. Fabbrini, E.; Sullivan, S.; Klein, S. Obesity and nonalcoholic fatty liver disease: Biochemical, metabolic, and clinical implications. Hepatology 2010, 51, 679-689. [CrossRef]

52. Zebisch, K.; Voigt, V.; Wabitsch, M.; Brandsch, M. Protocol for effective differentiation of 3T3-L1 cells to adipocytes. Anal. Biochem. 2012, 425, 88-90. [CrossRef] [PubMed]

53. Reeves, P.G.; Nielsen, F.H.; Fahey, G.C., Jr. AIN-93 purified diets for laboratory rodents: Final report of the American Institute of Nutrition ad hoc writing committee on the reformulation of the AIN-76A rodent diet. J. Nutr. 1993, 123, 1939-1951. [CrossRef] [PubMed]

54. Chen, X.; Huang, Z.; Wang, H.; Jia, G.; Liu, G.; Zhao, H.; Nie, H. Porcine phosphotyrosine interaction domain containing 1 modulates 3T3-L1 preadipocyte proliferation and differentiation. Biologia 2013, 68, 1010-1014. [CrossRef]

55. Bae, C.R.; Park, Y.K.; Cha, Y.S. Quercetin-rich onion peel extract suppresses adipogenesis by down-regulating adipogenic transcription factors and gene expression in 3T3-L1 adipocytes. J. Sci. Food Agric. 2014, 94, 2655-2660. [CrossRef]

56. Issa, R.; Boeving, M.; Kinter, M.; Griffin, T.M. Effect of biomechanical stress on endogenous antioxidant networks in bovine articular cartilage. J. Orthop. Res. 2018, 36, 760-769. [CrossRef]

Sample Availability: Samples of the compounds ginsenoside Rh2 are available from the authors. 